Original Article

\title{
An evaluation on cropping system of rice and corn in dry land during dry season
}

\author{
Zainal Arifin* and Amik Krismawati \\ Assessment Institute for Agricultural Technology (AIAT) of East Java, Indonesia
}

\begin{abstract}
Dry land has wide and diverse agroecosystem, which potential as growth source to produce dietary crops (foodstuff). The objective of the research was to study the appropriate managerial technique of cropping system for rice and corn to increase production and income of the farm operation in dry land during dry season. The research was conducted on dry land during dry season (DS) I in 2018 at Jatisari Village, Arjasa Subdistrict, Situbondo Regency, on the area of 10,000 $\mathrm{m}^{2}$ width. The research used Randomized Block Design with 4 treatments and 6 replications, includes : (a) Upland rice $(20 \mathrm{~cm}$ x $20 \mathrm{~cm})$, (b) Upland rice largo super $(40 \mathrm{~cm}$ x $20 \mathrm{~cm}$ x $10 \mathrm{~cm}),(\mathrm{c})$ Upland rice largo super $(40 \mathrm{~cm} \times 20 \mathrm{~cm} \times 10 \mathrm{~cm})+\mathrm{corn}(160 \mathrm{~cm} \times 40$ $\mathrm{cm})$, and (d) Corn $(75 \mathrm{~cm} \mathrm{x} 20 \mathrm{~cm})$. Results of the research showed that the intercropping system between upland rice largo super and corn produced higher yield, $8,151 \mathrm{~kg} / \mathrm{ha}$ DGH and 2,092 kg/ha grains of corn. Besides that, yield of corn trimming was 2,446 kg/ha fresh biomass. The increase production of intercropping upland rice largo super with corn has increase income of the farmers, IDR. 41,923,100 with R/C ratio 3.25 , so that it is economically feasible.
\end{abstract}

Keywords: Corn, cropping system, dry land, dry season, rice

Received: 13 December 2019 Revised: 05 May 2020 Accepted: 22 May 2020

\section{Introduction}

Dry land has low fertility with thin tillage and low organic matters, as well as limited water availability along with fluctuation in rainfall and distribution pattern that affects on the increase of planting indexes. In order to increase land productivity, balanced inorganic and organic fertilizers should be applied by utilizing bioagent for the plants. Based on result of the research by Mulyaningsih et al. (2015), it suggested that the application of biofertilizer of BioVam and Bioplus on upland rice may reduce $50 \%$ standard inorganic fertilizer (NPK) application as recommended without reducing the rice yield.

During dry season, water supply decreases, so that plants compete to absorb water (Turmudi, 2002). Annual rainfall is less than $2,000 \mathrm{~mm} /$ year with wet month duration is only 3 to 4 months that causes water supply, derived from rain, is only sufficient for one planting season (Mulyani 2013; Mulyani and Sarwani 2013). In order to obtain maximum productivity, it is important to apply the appropriate cropping system, which will be able to increase water supply, water use efficiency (WUE), and reduce erosion (Machado et al. 2008). Dry land is potential to increase cropping intensity by considering time duration between planting and harvest time as short as possible. In applying the technology, dry land management should be concerned with the effective technology

* Corresponding Author:

Zainal Arifin

Assessment Institute for Agricultural Technology (AIAT) of East Java, Indonesia

Jl. Raya Karangploso KM 4, Malang

Phone : 0341-494052 Fax : 0341-471255

e-mail: arifin_bptpjatim@yahoo.co.id selection that can be adopted by the farmers (Abdurachman et al., 2008)

Dry land productivity can be increased through intercropping because it is able to maintain water content and moisture, as well as to reduce erosion and increase soil fertility (Samosir, 1998). Moreover, Gonggo et al. (2007) suggested that intercropping system may increase land use effectiveness, minimize the risk of yield failure, and increase the farmers' income. Furthermore, Warsono et al. (2002) suggested that intercropping is one of alternatives on farming intensification program, which is appropriate to multiply the farming yield at less productive area. In accordance with Ningsih and Noor (2011), the important thing that must be concerned is the appropriate planting time and planting pattern, based on moisture balance analysis, so that the crops will not run the risk of water deficiency and, of course, it will increase the farmers' income. Location specific cropping system management with crop density arrangement requires adaptive and tolerant superior variety to limited water, short harvesting period, and high potential production in order to increase crop productivity (Husnain et al., 2016). Furthermore, Rasool et al. (2012) suggested that the arrangement of upland rice density in dry land, which is planted in an array manner (larikan), will increase the yield. Crop density arrangement using double row (jajar legowo) planting system may increase crop population per area unit (Erythrina and Zaini, 2014).

The objective of the research was to study the appropriate managerial technique of cropping system for rice and corn to increase production and income of the farm operation in dry land during dry season. 


\section{Methods}

\section{Materials}

The evaluation on cropping system of rice and corn in dry land was conducted at Jatisari Village, Arjasa Subdistrict, Situbondo Regency, on the area of $10,000 \mathrm{~m}^{2}$ widths. Rice crop used Inpago 10 variety and hybrid corn used HJ 21 variety. Doses of fertilizer application for monoculture are $300 \mathrm{~kg}$ Urea/ha, $300 \mathrm{~kg}$ Ponska/ha, and $1,000 \mathrm{~kg}$ organic fertilizer/ha (given to cover the planting hole). Fertilizer doses for rice crop are $200 \mathrm{~kg}$ Urea/ha, $300 \mathrm{~kg}$ Ponska/ha and 2,000 kg organic fertilizer/ha. The treatment on largo (larikan padi gogo) super applied the spacing of $40 \mathrm{~cm} \times 20 \mathrm{~cm} \times 10 \mathrm{~cm}$ along with the application of organic fertilizer and biofertilizer. For organic fertilizer, it will be supplemented with 4 sachets of biodecomposer M-Dec/2,000 kg organic fertilizer/ha. Before the seeds being germinated, rice seeds were soaked in biofertilizer solutions of Agrimeth by doses of 8 sachets $/ 50 \mathrm{~kg} / \mathrm{ha}$ rice seeds.

The need of corn seeds for monoculture $(75 \mathrm{~cm} \times 20$ $\mathrm{cm})$ is $20 \mathrm{~kg} / \mathrm{ha}$ with $1 \mathrm{seed} / \mathrm{hole}$, and for corn $(160 \mathrm{~cm} \mathrm{x}$ $40 \mathrm{~cm}$ ) intercropping with rice require $10 \mathrm{~kg} / \mathrm{ha}$ corn seeds with 2 seeds/hole, which are planted after the rice aged 10 day after planting (DAP). Rice planted by dibbling (tugal) 4-5 seeds per hole require $50 \mathrm{~kg} / \mathrm{ha}$.

\section{Methods}

The research on cropping system of rice and corn in dry land was conducted at Jatisari Village, Arjasa Subdistrict, Situbondo Regency. Characteristics of the region is based on Oldeman climate that has type E2 with 2 wet months and 6 dry months, as well as low soil fertility. The research used Randomized Block Design with 4 treatments and 6 replications, such as: (a) Upland rice $(20 \mathrm{~cm}$ x $20 \mathrm{~cm}$ ), (b) Upland rice largo super $(40 \mathrm{~cm}$ x $20 \mathrm{~cm}$ x $10 \mathrm{~cm})$, (c) Upland rice largo super $(40 \mathrm{~cm} \times 20 \mathrm{~cm} \times 10$ $\mathrm{cm})+\operatorname{corn}(160 \mathrm{~cm} \times 40 \mathrm{~cm})$, and $(\mathrm{d})$ Corn $(75 \mathrm{~cm} \times 20$ $\mathrm{cm})$.

Organic fertilizer was applied as basic fertilizer before planting the rice, but the organic fertilizer was applied to cover the planting hole when planting the corn. Inorganic fertilizers, $1 / 3$ dose of Urea and 1/2 dose of Ponska, were applied simultaneously when the rice was planted by dibbling; while $1 / 3$ dose of Urea and $1 / 2$ dose of Ponska were applied at 28 DAP and 1/3 dose of Urea was applied at 35 DAP. In corn cultivation, at 15 days before harvesting, trimming of stems on the cobs and leaves under the cobs to accelerate the ear drying in the field. The yield of corn trimming (biomass) can be used as feed.
Parameter of observation include: plant height, number of corn leaves, number of tillers, panicle of rice, number of cobs. After harvest time, weight of 1000 seeds of rice and corn, weight of corn trimming, yield of rice and corn (t/ha), Land Equivalent Ratio (LER). The increasing income or revenue of the farming operation was conducted by financial analysis in accordance with properness of the rice and corn farming operation using $\mathrm{R} / \mathrm{C}$ ratio.

LER is relative land area of intercropping to gain yield in comparison with monoculture. Mathematically, LER calculation (Palaniappan, 1985), is as follows:

$\mathrm{m}$

$\mathrm{LER}=\Sigma \underline{\mathrm{Yij}}$

i=1 Yii

Where, $Y_{i j}=$ Yield of the first component under intercropping condition,

$\mathrm{Y}_{\mathrm{ii}}=$ Yield of the component under monoculture in intercropping area.

If, LER $=1$ : Yield of intercropping equals to each yield of both crops in the same area of intercropping.

LER > 1: Yield of intercropping is higher (profitable) than each of both crops in the same area of intercropping.

LER < 1: Yield of intercropping is lower (unprofitable) than each of both crops in the same area of intercropping.

The farming properness of monoculture and intercropping, between rice and corn, was done by calculating $\mathrm{R} / \mathrm{C}$ ratio (Soekartawi, 2002) as follows:

$\mathrm{R} / \mathrm{C}$ ratio $=\mathrm{NPT} / \mathrm{BT}$

In which, $\mathrm{R} / \mathrm{C}=$ Revenue and Cost Ratio

$\mathrm{NPT}=$ Total production value (IDR/ha)

$\mathrm{BT}=$ Total cost value (IDR/ha)

If, R/C > 1: Feasible to be developed

$\mathrm{R} / \mathrm{C}=1$ : Break even

$\mathrm{R} / \mathrm{C}<1$ : Not feasible to be developed

\section{Results}

Location of the research is on dry land as old volcanic soil with low fertility.

\section{Growth and Yield}

Height of the rice crops, among upland rice, upland rice largo super, and upland rice largo super + corn, did not show any significant difference under observation at 30 DAP, 60 DAP, and 90 DAP (Tab. 1).

Table 1. Plant height of rice and corn in dry land of Jatisari Village, Arjasa Subdistrict, Situbondo Regency, DS I 2018

\begin{tabular}{|c|c|c|c|c|c|c|c|}
\hline & \multirow[t]{2}{*}{ Cropping system } & \multicolumn{3}{|c|}{ Plant height of rice $(\mathrm{cm})$} & \multicolumn{3}{|c|}{ Plant height of corn $(\mathrm{cm})$} \\
\hline & & 30 DAP & 60 DAP & 90 DAP & 30 DAP & 60 DAP & 90 DAP \\
\hline $\mathrm{A}$ & Upland rice & $31.4 \mathrm{a}$ & $66.8 \mathrm{a}$ & $94.2 \mathrm{a}$ & - & - & - \\
\hline B & Upland rice largo super & $27.3 \mathrm{a}$ & $71.3 \mathrm{a}$ & $99.9 \mathrm{a}$ & - & - & - \\
\hline $\mathrm{C}$ & Upland rice largo super +corn & $26.1 \mathrm{a}$ & $68.3 \mathrm{a}$ & $90.4 \mathrm{a}$ & $37.6 \mathrm{a}$ & $149.4 \mathrm{~b}$ & $151.8 \mathrm{~b}$ \\
\hline \multirow[t]{2}{*}{ D } & Corn & - & - & - & $47.6 \mathrm{a}$ & $195.1 \mathrm{a}$ & $191.9 \mathrm{a}$ \\
\hline & $\mathrm{C} \mathrm{V}(\%)$ & 11.41 & 6.28 & 7.71 & 20.97 & 3.09 & 2.84 \\
\hline
\end{tabular}

The numbers followed by the same letters in the same column are not significantly different from DMRT at the level of $5 \%$ 
The observation at 30 DAP, corns did not show significant difference in height, but at 60 DAP and 90 DAP, they showed some difference in height from cultivation of corn monoculture with corn against the intercropping between corn and upland rice largo super.
The cultivation of upland rice, upland rice largo super, and upland rice largo super + corn during the observation at 30 DAP, 60 DAP and 90 DAP did not significantly show any difference in numbers of rice tillers (Tab. 2).

Table 2. Number of rice tillers and number of corn leaves on dry land of Jatisari Village, Arjasa Subdistrict, Situbondo Regency, DS I 2018

\begin{tabular}{|c|c|c|c|c|c|c|c|}
\hline & \multirow[t]{2}{*}{ Cropping system } & \multicolumn{3}{|c|}{ Number of rice tillers } & \multicolumn{3}{|c|}{ Number of corn leaves } \\
\hline & & 30 DAP & 60 DAP & 90 DAP & 30 DAP & $60 \mathrm{DAP}$ & 90 DAP \\
\hline A & Upland rice & $7.6 \mathrm{a}$ & $21.8 \mathrm{a}$ & $22.0 \mathrm{a}$ & - & - & - \\
\hline B & Upland rice largo super & $6.7 \mathrm{a}$ & $19.4 \mathrm{a}$ & $19.9 \mathrm{a}$ & - & - & - \\
\hline $\mathrm{C}$ & Upland rice largo super + corn & $7.2 \mathrm{a}$ & $20.3 \mathrm{a}$ & $20.7 \mathrm{a}$ & $5.7 \mathrm{~b}$ & $11.4 \mathrm{a}$ & $11.4 \mathrm{a}$ \\
\hline $\mathrm{D}$ & Corn & - & - & - & $7.2 \mathrm{a}$ & $12.7 \mathrm{a}$ & $12.7 \mathrm{a}$ \\
\hline & $\mathrm{CV}(\%)$ & 16.39 & 15.99 & 17.75 & 6.81 & 8.60 & 7.92 \\
\hline
\end{tabular}

The numbers followed by the same letters in the same column are not significantly different from DMRT at the level of $5 \%$

The observation at 30 DAP, the corn in monoculture system showed the increase in numbers of leaf significantly in comparison with the corn in intercropping system with upland rice largo super, but at 60 DAP and 90 DAP, they did not any significantly difference in numbers of leaf. Upland rice cultivation has significantly produced the highest numbers of panicles per clump and then followed by upland rice largo super and upland rice largo super + corn (Tab. 3).

The mumbers of cobs have no significantly difference bet- ween monoculture and intercropping, but weight of biomass and weight of cobs on monoculture have significantly difference in comparison with intercropping. Rice and corn cultivation, both monoculture and intercropping, did not show any significant difference for weight of 1000 seeds (Tab. 4).

In monoculture system, rice and corn cultivation showed higher yield of seeds for each of them, in comparison with intercropping system (Tab. 5). Upland rice largo super intercropped with corn has the highest LER of 1.27.

Table 3. Number of panicles/clumps of rice and number of cob/corn plants and weight of fresh corn biomass and weight of corn cobs on dry land of Jatisari Village, Arjasa Subdistrict, Situbondo Regency, DS I 2018

\begin{tabular}{|c|c|c|c|c|c|}
\hline & Cropping system & $\begin{array}{c}\text { Number of } \\
\text { panicles/clumps of rice }\end{array}$ & $\begin{array}{c}\text { Number of cob/corn } \\
\text { Plants }\end{array}$ & $\begin{array}{l}\text { Weight of corn biomass } \\
\text { (t/ha fresh) }\end{array}$ & $\begin{array}{l}\text { Weight of corn cobs } \\
\text { (t/ha dry) }\end{array}$ \\
\hline A & Upland rice & $16.7 \mathrm{a}$ & - & - & - \\
\hline B & Upland rice largo super & $14.1 \mathrm{~b}$ & - & - & - \\
\hline $\mathrm{C}$ & Upland rice largo super + corn & $11.3 \mathrm{c}$ & $1.1 \mathrm{a}$ & $2.4 \mathrm{~b}$ & $3.0 \mathrm{~b}$ \\
\hline \multirow[t]{2}{*}{$\mathrm{D}$} & Corn & - & $1.2 \mathrm{a}$ & $7.0 \mathrm{a}$ & $8.8 \mathrm{a}$ \\
\hline & $\mathrm{C} \mathrm{V}(\%)$ & 8.77 & 3.39 & 15.18 & 18.94 \\
\hline
\end{tabular}

The numbers followed by the same letters in the same column are not significantly different from DMRT at the level of 5\%

Table 4. Weight of 1000 seeds of rice and corn on dry land of Jatisari Village, Arjasa Subdistrict, Situbondo Regency, DS I 2018

\begin{tabular}{|c|c|c|c|}
\hline & Cropping system & $\begin{array}{l}\text { Weight of } 1000 \text { grains } \\
\text { of rice }(\mathrm{g})\end{array}$ & $\begin{array}{l}\text { Weight of } 1000 \text { grains } \\
\text { of corn }(\mathrm{g})\end{array}$ \\
\hline A & Upland rice & $28.0 \mathrm{a}$ & - \\
\hline B & Upland rice largo super & $30.1 \mathrm{a}$ & - \\
\hline $\mathrm{C}$ & Upland rice largo super + corn & $30.0 \mathrm{a}$ & $137.0 \mathrm{a}$ \\
\hline \multirow[t]{2}{*}{$\mathrm{D}$} & Corn & - & $139.2 \mathrm{a}$ \\
\hline & $\mathrm{C} \mathrm{V}(\%)$ & 5.66 & 1.77 \\
\hline
\end{tabular}

The numbers followed by the same letters in the same column are not significantly different from DMRT at the level of 5\%

Table 5. Yields of rice dried grain harvest (DGH), corn dried grain and LER on dry land of Jatisari Village, Arjasa Subdistrict, Situbondo Regency, DS I 2018

\begin{tabular}{clccc} 
Cropping system & $\begin{array}{c}\text { Yield of rice } \\
\text { (t/ha DGH) }\end{array}$ & $\begin{array}{c}\text { Yield of corn } \\
\text { (t/ha dry grain) }\end{array}$ \\
\hline A & Upland rice & $6.0 \mathrm{~b}$ & - \\
$\mathrm{B}$ & Upland rice largo super & $8.6 \mathrm{a}$ & - \\
$\mathrm{C}$ & Upland rice largo super +corn & $8.2 \mathrm{a}$ & 1 \\
$\mathrm{D}$ & Corn & - & $2.1 \mathrm{~b}$ & $6.2 \mathrm{a}$ \\
\hline & & 8.65 & 1.27 \\
\hline
\end{tabular}

The numbers followed by the same letters in the same column are not significantly different from DMRT at the level of 5\%

\section{Rice and Corn Farming}

The cropping system management of rice and corn in dry land at DS I 2018 showed that the best $\mathrm{R} / \mathrm{C}$ ratio for yield of rice and corn was found by applying intercropping system of upland rice largo super with corn (Fig. 1 and Tab. 6). 


\begin{tabular}{|c|c|c|c|c|c|c|c|c|}
\hline \multirow{2}{*}{ Activity } & \multicolumn{2}{|c|}{ Upland rice } & \multicolumn{2}{|c|}{$\begin{array}{l}\text { Upland rice } \\
\text { largo super }\end{array}$} & \multicolumn{2}{|c|}{$\begin{array}{c}\text { Upland rice largo super + } \\
\text { corn }\end{array}$} & \multicolumn{2}{|c|}{ Corn } \\
\hline & vol. & $\begin{array}{r}\text { value } \\
\text { (IDR) }\end{array}$ & vol. & $\begin{array}{r}\text { value } \\
\text { (IDR) } \\
\end{array}$ & vol. & $\begin{array}{r}\text { value } \\
\text { (IDR) } \\
\end{array}$ & vol. & $\begin{array}{l}\text { value } \\
\text { (IDR) }\end{array}$ \\
\hline \multicolumn{9}{|l|}{ A. Labor $(W D)$} \\
\hline 1. Tillage & 10 & 1.000 & 10 & 1.000 & 10 & 1.000 & 10 & 1.000 \\
\hline 2. Planting & 30 & 1.800 & 34 & 2.040 & 40 & 2.400 & 22 & 1.320 \\
\hline 3. Fertilization & 8 & 480 & 8 & 480 & 8 & 480 & 8 & 480 \\
\hline 4. Weeding & 35 & 2.100 & 35 & 2.100 & 35 & 2.100 & 20 & 1.200 \\
\hline 5. Pest control & 6 & 360 & 6 & 360 & 6 & 360 & 4 & 240 \\
\hline 6. Irrigation & 5 & 300 & 5 & 300 & 5 & 300 & 4 & 240 \\
\hline 7. Corn trimming & & & & & 4 & 240 & 8 & 480 \\
\hline 8. Harvesting & 24 & 1.440 & 24 & 1.440 & 30 & 1.800 & 18 & 1.080 \\
\hline 9. Post harvest & 12 & 720 & 13 & 780 & 18 & 980 & 12 & 720 \\
\hline \multicolumn{9}{|l|}{$\begin{array}{l}\text { B. Prod. Facilities }(\mathrm{kg}) \\
\text { 1. Seed }(\mathrm{kg})\end{array}$} \\
\hline - Rice & 40 & 360 & 50 & 450 & 50 & 450 & & \\
\hline - Corn & & & & & 10 & 450 & 20 & 900 \\
\hline \multicolumn{9}{|l|}{ 2. Fertilizer $(\mathrm{kg})$} \\
\hline - Organic & 2.000 & 1.000 & 2.000 & 1.000 & 2.000 & 1.000 & 1.000 & 500 \\
\hline - Urea & 200 & 360 & 200 & 360 & 200 & 360 & 250 & 450 \\
\hline - Phonska & 250 & 575 & 250 & 575 & 250 & 575 & 250 & 575 \\
\hline - Agrimeth (Sachet) & & & 10 & 60 & 10 & 60 & & \\
\hline - M-Dec (Sachet) & & & 4 & 40 & 4 & 40 & & \\
\hline 3. Pesticide (Bottle) & 4 & 240 & 4 & 240 & 4 & 300 & 2 & 120 \\
\hline C. Production Cost & & 10.735 & & 11.225 & & 12.895 & & 9.305 \\
\hline D. Yield of rice (DGH) & 6.016 & 25.267 & 8.560 & 35.952 & 8.151 & $34.234,2$ & & \\
\hline E. Yield of corn (dried grains) & & & & & 2.092 & 7.322 & 6.708 & 23.478 \\
\hline F. Weight of corn trimming & & & & & 2.446 & 366,9 & 7.094 & 1.064 \\
\hline G. Total of yield & 6.016 & 25.267 & 8.560 & 35.952 & 10.243 & $41.923,1$ & 6.708 & $24.542,1$ \\
\hline H. Profit & & 14.532 & & 24.727 & & 29.028 & & $15.237,1$ \\
\hline I. $R / C$ ratio & & 2,35 & & 3,20 & & 3,25 & & 2,64 \\
\hline
\end{tabular}

Information :

Prices of rice grain (DGH): IDR. 4,200/kg

Price of corn dry grains : IDR. $3,500 / \mathrm{kg}$

Price of biomas fresh (corn trimming) of feed : IDR. 150/kg

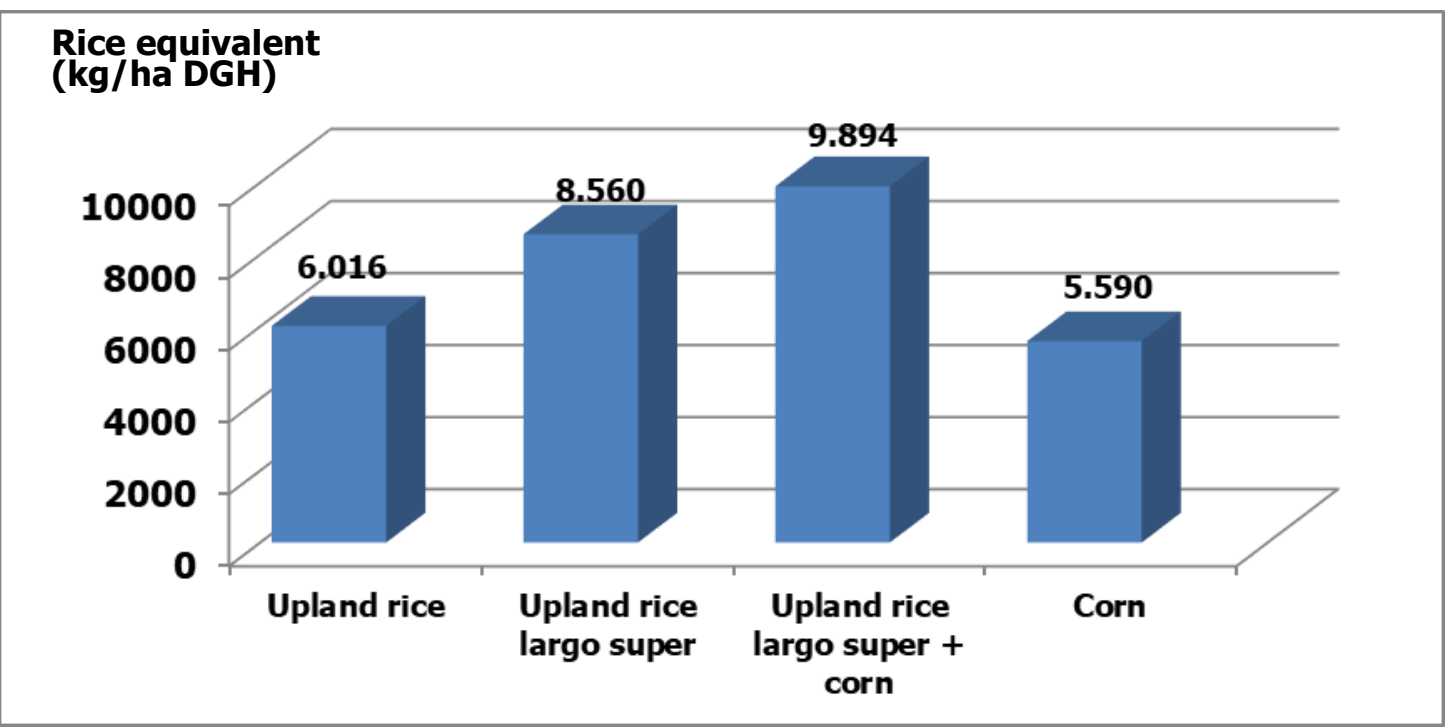

Figure 1. Rice equivalent yield from the management of rice and corn cropping systems on dry land of Situbondo Regency at DS I 2018

\section{Discussion}

The soil in location of the research containing $\mathrm{C}$ organic was very low, $\mathrm{N}$-total and $\mathrm{P}_{2} \mathrm{O}_{5}$ were low and $\mathrm{K}_{\mathrm{dd}}$ was medium with sandy clay loam texture and soil solum $5.5-9.5 \mathrm{~cm}$ were very shallow. The dominant shallow soil with solum condition in dry land area of dry climate (BBSDLP 2012; Dariah et al. 2013; Mulyani and Sarwani 2013; Mulyani 2013), causing tolerable soil loss becomes very low.

\section{Growth and Yield}

On observation at 30,60, and 90 DAP, height of the rice plant did not show significant difference. The corn height at 30 DAP did not significant difference, but at 60 and 90 DAP, they showed significant difference through monoculture in comparison with the intercropping between corn and upland rice largo super.

Numbers of upland rice tiller did not show significant difference during observation at 30,60, and 90 DAP. In 
accordance with Kurniasih et al. (2008), the increasing radiation interception by canopy of the plant (monoculture) may increase numbers of rice panicles. Furthermore, Sasmita et al. (2006) suggested that a consistency occurred between shade tolerance and adaptive toward intercropping condition, rice and corn, by the emergence of similar response of growth and yield of upland rice. The corn, which was cultivated in monoculture system and intercropped with upland rice largo super, did not show significant difference on numbers of cobs per plant.

At 30 DAP, the corn that was cultivated in monoculture has significantly increased its numbers of leaf in comparison with the intercropped corn, but it did not show significant difference at 60 and 90 DAP.

In monoculture system, weight of cobs was higher ( $8.8 \mathrm{t} / \mathrm{ha}$ dry), while in intercropping system between corn and largo super produced 3.0 t/ha dry. Trimming the corn leaf, 15 days before harvesting the monocultured corn, has significantly produced the highest weight of trimming in comparison with the intercropped corn. High monocultured corn trimming (7.0 t/ha fresh biomass) is affected by high population of corn (twice more) than intercropped corn (2.4 t/ha fresh biomass). In accordance with Permanasari and Kastono (2012), the corn leaf trimming may not decrease the yield if it is done in the right time, during the photosynthetic process; the leaf has not been optimal. Fresh biomass of corn has great potential to be used for feed, which is difficult to be available during dry season.

Weight of 1000 seeds of rice and corn, which are cultivated in monoculture, has increased weight of seeds in comparison with the intercropping system, but such increase of seed weight did not any significant difference.

The highest yield of rice was significantly found on upland rice largo super by monoculture were $8.6 \mathrm{t} / \mathrm{ha}$ DGH, followed by upland rice largo super intercropped with corn were $8.2 \mathrm{t} / \mathrm{ha} \mathrm{DGH}$, and upland rice $6.0 \mathrm{t} / \mathrm{ha}$ DGH. These yields showed that the application of upland rice largo super has increased the yield 2.2-2.6 t/ha DGH in comparison with upland rice. Less light intensity intercepted by the canopy may affect low production of upland rice intercropped with corn. Along with results of the research by Dewi et al. (2004), the closer the spacing of sweet corn, the lower light may be intercepted by the rice plants. Low light intensity may disturb photosynthesis and carbohydrate synthesis, as well as reduce growth and productivity of the plants (Chozin et al., 1999). In general, the shade affects the processes of photosynthesis, respiration, transpiration, nitrate reduction, protein synthesis, hormone production, translocation, and aging. The shade also changes micro-climate elements, such as temperature, soil temperature, and relative humidity, as well as reduce air circulation from outside the canopy.

The highest yield of corn was significantly found by monoculture system in comparison with intercropping, monoculture corn produced 6.2 t/ha dry grains and intercropping system between corn and upland rice largo super produced $2.1 \mathrm{t} / \mathrm{ha}$ dry grains, or increase $4.1 \mathrm{t} / \mathrm{ha}$ dry grains.

Intercropping system between upland rice largo super and corn has LER 1.27, so that the land use efficiency gets $27 \%$ profit in comparison with monoculture system of rice and corn. Therefore, in order to gain yield of upland rice largo super $8.2 \mathrm{t} / \mathrm{ha} \mathrm{DGH}$ and corn 2.1 dry grains (Table 9), it required land equals to 1.27 ha to obtain the same yield as in monoculture. It conformed to the opinion of Hairid (2002, in Susanti et al., 2017), it is presumed that intercropping system is more productive than monoculture if LER is more than one. Along with result of the research by Arifin et al. (2014), it reported that the application of intercropping between soybean and corn has increased LER and income of the farming operation, yield of corn and soybean seeds, as well as fresh biomass of the corn trimming yield. Moreover, result of the research by Prasetyo et al. (2009) suggested that intercropping between upland rice and castor plants (Jatropha curcas L.) resulted grain (unhulled rice) $5.16 \mathrm{t} / \mathrm{ha}$, by yield ratio 1.02 and LER value is 1.42

\section{Rice and Corn Farming}

Based on analysis of rice and corn farming, by the application of monoculture system for upland rice largo super, the yield resulted $8,560 \mathrm{~kg} / \mathrm{ha} \mathrm{DGH}$ and $\mathrm{R} / \mathrm{C}$ ratio 3.20; while the yield from intercropping system between upland rice largo super and corn even it showed a little decrease was $8,151 \mathrm{~kg} / \mathrm{ha} \mathrm{DGH}$, but it was contributed from yield of corn seeds, 2,092 $\mathrm{kg}$ grains $(9,894 \mathrm{~kg} / \mathrm{ha}$ equals to DGH), besides that the yield of corn's leaf trimming was $2,446 \mathrm{~kg} / \mathrm{ha}$ fresh biomass, so that the income or revenue increased IDR. 41,923,100 and R/C ratio was 3.25 .

\section{Acknowledgement}

Special thanks to Mrs. Indriana Ratna Dewi, SP for her assistance in the implementation and plant observation during the research, as well as to Mr. Dr. Chendy Tafakresnanto, MP who has given the access and support during implementation of the research.

\section{References}

Abdurrahman, A., Dariah, A., \& Mulyani, A. (2008). Strategi dan teknologi pengelolaan lahan kering mendukung pengadaan pangan nasional. Jurnal Litbang Pertanian, 27(2), 43-49.

Arifin, Z., Suwono, \& Arsyad, D. M. (2014). Pengaruh sistem tanam dan pemangkasan tanaman terhadap pertumbuhan serta hasil jagung dan kedelai, 17(1), 15-26. doi:10.21082/ jpptp.v17n1.2014.p\% 25p

BBSDLP. (2012). Suboptimal land: potential, opportunities, and problems of utilization to support the food security program. In The Sub-Optimal Land Seminar, Palembang, March 2012. Ministry of Research and Technology.

Chozin, M. A., Sopandie, D., Sastrosumarjo, S., \& Suwarno. (1999). Physiology and genetic of upland rice adaptability to shade. Final Report of Graduate Team Research Grant, URGE Project.. Jakarta. Directorate General of Higher Education, Ministry of National Education.

Dariah, A., Sutono, \& Subiksa, I. G. M. (2013). Soil management system for dry climates dry land. (Eds. Nurida and Purnomo). Agency for Agricultural Research and Development. Ministry of Agriculture. IAARD Press. 63p.

Dewi, S. S., Soelistyono, R., \& Suryanto, A. (2014). Study of cropping patterns of upland rice (Oryza sativa L.) with sweet corn (Zea mays saccharatasturt L.). Jurnal Produksi Tanaman, 2(2), 137144.

Erythrina, \& Zaini, Z. (2014). Budi daya padi sawah sistem tanam jajar legowo: tinjauan metodologi untuk mendapatkan hasil optimal. Jurnal Litbang Pertanian, 33(2), 79-86. doi:10.21082/jp3.v33n2.2014.p79-86 
Gonggo, B. M., Turmudi, E., \& Brata, W. (2003). Respon Pertumbuhan dan hasil ubi jalar pada sistem tumpangsari ubi jalar-jagung manis di lahan bekas alang-alang. Jurnal Ilmu-Ilmu Pertanian Indonesia, 5(1), 34-39.

Husnain, H., Nursyamsi, D., \& Syakir, M. (2016). Teknologi pemupukan mendukung jarwo super. Jurnal Sumberdaya Lahan, 10(1), 1-10. doi: 10.2017/jsdl.v6n2.2012.\%25p

Kurniasih, B. A., Fatimah, S., \& Purnawati, D. A. (2008). Karakteristik perakaran tanaman padi sawah IR64 (Oryza sativa L.) pada umur bibit dan jarak tanam yang berbeda. Jurnal Ilmu Pertanian, 15(1), 15-25.

Machado, S., Petrie, S., Rhinhart, K., \& Ramig, R. E. (2008). Tillage effects on water use and grain yield of winter wheat and green pea in rotation. Agronomy Journal, 100(1), 154-162. doi:10.2134/agrojn12006.0218

Mulyani, A. (2013). Characteristics and potential of dry climate dry land for agricultural development in East Nusa Tenggara. in Proceedings of the National Seminar on Dryland Agricultural Innovation. Kupang 4-5 September 2012. Center for the Assessment and Development of Agricultural Technology. Agency for Agricultural Research and Development. Ministry of Agriculture. p. 593-600

Mulyani, A., \& Sarwani, M. (2013). Karakteristik dan potensi lahan sub optimal untuk pengembangan pertanian di Indonesia. Jurnal Sumberdaya Lahan, 7(1), 47-58 doi:http://dx.doi.org/10.2017/jsdl.v7n1.2013.\%25p

Mulyaningsih, E. S., Sukiman, H., Ermayanti, T. M., \& Lekatompessy, S. (2015). Respon padi gogo terhadap pupuk hayati di lahan kering Kabupaten Konawe Selatan, Sulawesi Tenggara. Jurnal Pengkajian dan Pengembangan Teknologi Pertanian, 18(3) 251-261

Ningsih, R. D., \& Noor, A. (2011). Determination of the right planting time to reduce the loss of upland rice yields in Tanah Bumbu Regency, South Kalimantan. In Abdulrachman et al. (eds). Proceedings of the Scientific Seminar on the Results of Nationa Rice Research 2010. Variability and Climate Change: Its Influence on National Food Independence. Indonesian Center for Rice Research. Agency for Agricultural Research and Development. p: 793-803.
Palaniappan, S. P. (1985). Cropping system in the tropics: principles and management. India: Wiley Eastern Limited and Tamil Nadu Agricultural University.

Permanasari, I., \& Kastono, D. (2012). Pertumbuhan tumpangsari jagung dan kedelai pada perbedaan waktu tanam dan pemangkasan jagung. Jurnal Agroteknologi, 3(1), 13-20. doi:10.24014/ ja.v3i1.90

Prasetyo, E. I., Sukardjo, \& Pujiwati, H. (2009). Produktivitas lahan dan NKL pada tumpangsari jarak pagar dengan tanaman pangan. Jurnal Akta Agrosia, 12(1), 51-55.

Rasool, F. U., Habib, R., \& Bhat, M. I. (2012). Evaluation of plan spacing and seedlings per hill on rice (Oryza sativa L.) productivity under temperate conditions. Pakistan Journal Agriculture $\quad$ Sciences, $\quad 49(2), \quad 169-172$ doi:10.21162/PAKJAS/17.5324.

Samosir, S. S. R. (1998). Dry land management. Paper presented at the National Seminar II Dryland Cultivation. In the Framework of Unhalu Anniversary XV, Kendari. In Warsono et al (eds.). Integrated Agriculture A Strategy to Achieve Sustainable Agriculture. Bogor Agricultural Institute.

Sasmita, P., Purwoko, B. S., Sujiprihati S., Hanarida, I., Dewi, I. S., \& Chozin, M. A. (2006). Evaluasi pertumbuhan dan produksi padi gogo haploid ganda toleran naungan dalam sistem tumpang sari. Jurnal Agronomi Indonesia (Indonesian Journal of Agronomy), 34(2), 79-86. doi:10.24831/jai.v34i2.1283

Soekartawi. (1988). Basic principles of agricultural communication Jakarta: UI Press.

Susanti, E., Susylowati, S., \& Pranoto, H. (2017). Pertumbuhan dan daya hasil tumpang sari jagung (Zea mays L.) dan kacang tanah (Arachis hypogaea L.) terhadap waktu dan posisi pemangkasan jagung. ZIRAA'AH, 42(1), 47-57. doi:10.31602/zmip.v42i1.642

Turmudi, E. (2002). Kajian pertumbuhan dan hasil tanaman dalam sistem tumpangsari jagung dengan empat kultivar kedelai pada berbagai waktu tanam. Jurnal Ilmu-Ilmu Pertanian Indonesia 4(2), 89-96

Warsono, I. U., Gusti Ayu, K. S., Luluk, P. E., Sri, W., Hesti, Eva, O., Endang, H., Rudi, Desyanti, Elis, N. H., \& Suwena, M. (2002). Pertanian terpadu suatu strategi untuk mewujudkan pertanian kelanjutan. Bogor: Bogor Agricultural Institute. 